\title{
Female leadership and a competency-based portrait of a leader as perceived by female students
}

\author{
Tatyana Monastyrskaya \\ Siberian State University of Telecommunications and Information Sciences \\ Kirova 86, 630102, Novosibirsk \\ Russian Federation \\ e-mail: t.monastyrskaya@mail.ru \\ Gleb Toropchin \\ Novosibirsk State Technical University \\ K. Marx Ave. 20, 630073, Novosibirsk \\ Russian Federation \\ e-mail: glebtoropchin@mail.ru \\ Aleksandr Katsura \\ Siberian State Aerospace University \\ “Krasnoyaskiy Rabochiy”Ave. 31, 660037, Krasnoyarsk \\ Russian Federation \\ e-mail: pnk-sibsau@mail.ru
}

\begin{abstract}
Leadership can guarantee dominant positions for organisations pursuing their goals in entrepreneurship, business, politics, science as well as social and outreach activities and education programmes. Female leadership is most pronounced in this area. In spite of a significant number of studies in the given sphere, we come to a conclusion that the concept of female leadership remains undeveloped to a large extent. Whereas there is no universal model of leadership qualities, there is also a point of view that these can be formed and developed. Competency approach is used in the higher school educational process for forming leadership qualities in students. Leadership qualities are formed during the entire process of training within different disciplines in the curricula. There exist training programmes and other special courses allowing the students to reveal their leadership potential. Within this applied social study, we make an attempt to describe a competency-based model of a female leader as seen by female students of different majors and grades as well as analyse female students' opinion about the possibility of developing leadership qualities and their motivation for participation in training sessions and courses aimed at developing these competencies.

We draw a conclusion that training programmes for forming and developing leadership competencies can be designed for mixed groups of female students, i.e. students of different majors and grades. Moreover, we show an outline competency-based model of a female leader created on the ground of a group interview with female students of different majors.
\end{abstract}

\section{Introduction}

In the contemporary scholarly literature problems of female leadership are regarded from the standpoint of necessary leadership skills, female leader's behaviour in various situations as well as situations themselves in which women display their leadership skills.

Theory of status and gender role theory are considered the most promising ones. According to Yermakova (2013), each of the approaches explains and shows the opportunities of effective leadership for women, but none of the approaches on the whole gives a full explanation of all the existing experiments. An analysis of social and psychological studies also shows that women's gender role in terms of leadership is not reflected well enough at present (see e.g. Volchik et al. 2018).

A number of Russian theoretical and applied studies in the area of female leadership contains emphasis on the fact that women have higher leadership potential than men. Women's advantages in management competencies affect the overall leadership efficiency (Khayurullina and Khayrullina 2014). These authors (unlike foreign researchers) also mention that Russian women possess good strategic thinking. Vygodova and Demura (2016) see women's advantages most of all in their ability to concentrate on different things at the same time, taking responsibilities, discipline, behaviour based on trustworthiness, high level of sociability, a quicker adaptiveness to change. Klyukina (2016) claims that women have even higher motivation for achievement and striving for leadership. Males have a considerable advantage in just one management competency: development of strategic 
vision (Brezhneva et al. 2016). As it is sometimes shown by sociological research, women can be good leaders in the spheres where communication skills matter, e.g. in the sphere of education (Mollaeva 2014).

Russian women's opinion of leadership is reflected in the paper by Goryunova (2014). The author states that in Russia there is a widespread conviction that leadership should not be characteristic of women. An attempt to combine care and family responsibilities is less successful for Russian women than for their counterparts from other countries. In addition, Bataeva (2014) claims that women are more psychologically prone to constantly stand up for their right for leadership. Besides, moral support of subordinates is important for female managers.

Training courses aimed at developing leadership competencies become more popular on the market of educational services. Such programmes and courses presuppose development of specific leadership competencies, i.e. designing a curriculum founded on a competency-based model of female leadership formed by experts. However, as stated by Kropachyova and Suvorova (2016) based on the obtained results of their study, experts and respondents have quite substantial differences in the perception of qualities of a female leader, whereas stereotypical images of female leadership include a fragmentary patchwork of emotional and cognitive components in a holistic worldview. Researching gender stereotypes in students, authors come to a conclusion that students very frequently focus their attention of negative stereotypes of female leadership, including women's personal, professional and behavioural characteristics. According to Bakster and Erlikh (2017), lecturers do not always have a holistic basis for developing leadership curricula for women. Given absence of such a basis very often the same curricula for both men and women are utilised. In this case it is conjectured that gender does not matter for developing leadership. Such an approach will not facilitate formation of a sustainable leadership potential.

It appears that female students rather often have a considerable leadership potential. As is underlined Dolzhenkova (2017) in her work, female students should not ignore problems and opportunities connected with personal growth, their femininity when studying at university. This could be assisted by training courses, master classes aimed at developing leadership and succeeding in professional activities.

This paper discusses the phenomenon of female leadership in Russian and global scientific discourses of the $21^{\text {st }}$ century, demonstrating various approaches towards the description of this phenomenon.

\section{Literature review}

The issue of female leadership has been studied extensively by numerous international authors. Interestingly enough, major companies exercise their social responsibilities by undertaking scholarly research in order to scrutinise and facilitate women's representation in business. McKinsey (2008) published their paper focused on underrepresentation of women in European structures proving that an increased percentage of females in management teams leads to positive dynamics in terms of performance (McKinsey 2008). The study was based on behaviourist approach. "KPMG Women's Leadership Study" can serve as another example of such an investigation (KPMG 2015). The authors come to a conclusion that there are several key areas which need special focus (these are socialising leadership since childhood, using role models and networking and providing corresponding corporate programmes).

Besides, research conducted by Eagly et al. (2003) and showed that women exhibit several leadership traits more often than men (role model and inspiration being among them). Some researchers pay attention to women's leadership programmes: Berryman-Fink et al. (2003) focus on gender equity at universities. The Women's Leadership Programme, as it was implemented in the University of Cincinnati, helped to change gender balance among administrative staff of the university and gained positive feedback of the participants.

In addition, Place and Vardeman-Winter (2018) made an attempt to give an overview of the female leadership phenomenon in public relations. They found out that females are strongly underrepresented in the described area of activity, whereas the topic has not yet been given enough attention and it is necessary to expand the field of study in this regard applying different methods and approaches in order to make research in this area more robust.

Furthermore, Solomon and Secrest (2017) view networks of support as one of the methods to facilitate female leadership. It is a way to tackle challenges and difficulties women encounter when developing leadership skills. The authors describe it as "circle methodology", with these circles being beneficial for all participants.

Moreover, Khwaja (2017) conducted research connected with female leadership in academia, which is predetermined by the fact that more women are represented in the tertiary education system than ever before. The study was focused on the analysis of inaugural speeches made by both male and female presidents. It was found that female leaders are more prone to using so-called guarded languages in their addresses. It is interesting to see how women penetrate university management, which has traditionally been regarded as a male realm.

Additionally, Adjorlolo et al. (2013) analysed leadership competencies in women in mixed gender and single-gender environments using such methods as interviews and self-assessment techniques. Their case study was related to female university students displaying leadership qualities, and it appeared that female leaders were 
even sometimes intimidated by male leaders in mixed-gender milieu. As such, emerging young female leaders require support in forming their competencies (including mentoring).

One more interesting topic is how women are adapting to branches traditionally described as "men's realm". Shetty (2017) looks at the factor of women's leadership in IT Sector in Bangalore, India. As for the relevance of this topic, in India gender gap is growing, whereas women can build involving and collaborative environment at work. Researcher also gives certain practical recommendations (such as training programmes etc.), stressing that female leadership provides sustainable growth of a company, ensures financial stability and diversity in terms of corporate culture.

On the other hand, Esser et al. (2018) and others reviewed how male leaders perceive female leadership as it is, especially in ICT. They underlined that professional qualities are not exclusive attributes that form a female leader: she should also have certain skills of interpersonal communication and a lot depends on their behavior patterns. The analysis of the theoretical material and present experience of applied research in female leadership made it possible to single out the problematic field of the given study: the possibility of forming leadership potential in women based on female university students' opinions. The main tasks were: scrutinizing personal qualities and competences of a female leader, defining the possibility of developing leadership potential, readiness to develop leadership competencies in female university students of various years of study and majors.

\section{Research methodology}

Competency-based approach is the methodological basis of the given study, as it allows to consider female leadership from the standpoint of developing certain competencies which will assist female students in acquiring leadership positions in their future professional activity.

The study was carried out in two stages. At the first one, questionnaire survey was used as a research method. The goal of the survey was to find out what competencies are considered the most important for a leader by female students, whether one can develop such competencies and whether female students are ready to try to develop the given competencies in the process of studying at university in order to attempt to become leaders in their professional activity in the future.

When developing sociological tools for studying female leadership we took the set of competencies and survey questions designed within the framework of REBUS project (2017) as a basis. The survey was also extended thanks to adding questions about personal qualities of a female leader. At the second stage of the study we conducted three group interviews whose goals were to discuss the obtained survey results and create an outline of a competency-based model for a female leader.

The study lasted from 20.02.2018 to 20.03.2018. 378 female students from universities of Novosibirsk and Krasnoyarsk $\left(1^{\text {st }}, 2^{\text {nd }}, 3^{\text {rd }}, 4^{\text {th }}\right.$ and $5^{\text {th }}$ years of study and Master programme $)$ took part in the present research. The respondents had the following majors: engineering, civil engineering (building), social sciences and humanities, mathematics, physics and IT.

\section{Leadership competencies and opportunities: analysing female students' opinions}

In the questionnaire-based survey, female students were offered a list of competencies that a leader requires, out of which they had to choose three most important ones (in accordance with their opinions). Afterwards, female students chose the ones they would like to develop in themselves (Fig. 1). The most significant out of the competencies suggested in the list for female students were: working with others, motivation and persistence and taking initiative. Among the least significant competencies for a leader were the following ones: coping with ambiguity, mobilizing resources, learning through experience and ethical and sustainable thinking. However, the priority in terms of the competencies female students would like to develop is somewhat different. In the first place, female students are interested in developing such competencies as financial and economic literacy, motivation and persistence (in this case, the priorities coincide) and creativity. As for the least significant qualities in terms of developing competencies, these were valuing ideas, mobilizing resources and learning through experience. The analysis of the survey results allows one to suppose that curricula and training programs for developing leadership competencies should be flexible and allowing for participants' perception of their own progress during the training. The analysis of importance of leadership competencies for students of different years of study showed that such competencies as working with others, motivation and persistence and taking initiative are the most important ones for 1st and 3rd year students. For 2nd year students, these competencies are also important, though mobilizing others is somewhat more important that taking initiative. As for 4th year students, they marked such most important competencies as working with others, taking initiative and vision. Mobilizing others, motivation and persistence and mobilizing resources are important for $5^{\text {th }}$ year students and Master students. As such, one can single out a nucleus of competencies which is equally important for students in all years. Our analysis of female students' answers to the given questions showed that the perception of leadership competencies does not have a strong correlation with the year and major field of study (Figure 1). 


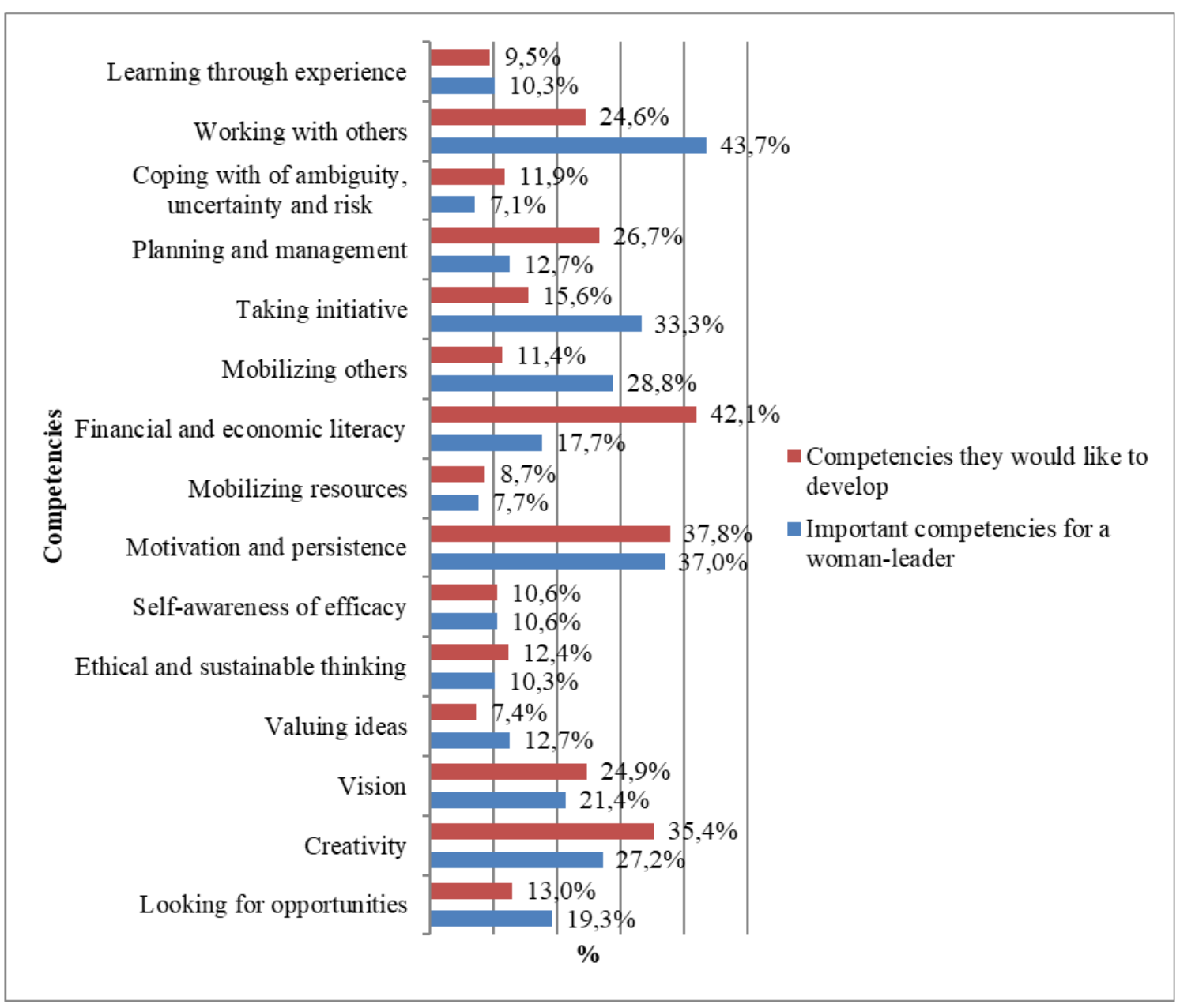

Fig. 1. Important leadership competencies and the will to develop them $(\mathrm{N}=378)$ Source: own results

The efficiency of courses and training programmes in the area of developing leadership competencies has a direct dependence on the students' motivation. Motivation, in its turn, is determined by how strongly the students are sure about the feasibility of the goal set. The assessment of the possibilities of developing leadership competencies within the framework of curricula and training programmes is presented in Table 1 below.

Table 1. Developing leadership competencies within the framework of curricula and training programmes

\begin{tabular}{|l|l|l|l|l|}
\hline $\begin{array}{l}\text { Assessment of the opportunities } \\
\text { for developing leadership } \\
\text { competencies }\end{array}$ & Frequency & Percent & Valid percent & $\begin{array}{l}\text { Accumulated } \\
\text { percent }\end{array}$ \\
\hline Yes, I am sure & 69 & 18.3 & 18.3 & 18.3 \\
\hline Maybe, to some extent & 255 & 67.5 & 67.5 & 85.7 \\
\hline I doubt it & 34 & 9.0 & 9.0 & 94.7 \\
\hline $\begin{array}{l}\text { No, it is a talent which is either } \\
\text { there or not }\end{array}$ & 20 & 5.3 & 5.3 & 100.0 \\
\hline Total & 378 & 100.0 & 100.0 & \\
\hline
\end{tabular}

The results of our survey showed that female students are not sufficiently sure that leadership competencies can be developed. Only $18.3 \%$ of those surveyed are sure about the possibilities of developing the competencies, $9 \%$ expressed their doubt, $5.3 \%$ deny such a possibility, $67.5 \%$ consider developing leadership competencies partly possible. Analysis of the assessment of the possibilities of developing leadership competencies depending on the year of study and major by the female students showed that the pessimism regarding the possibilities of developing leadership competencies somewhat increases during last stages of obtaining a university degree. 
Female students majoring in IT and mathematics are more optimistic about developing competencies, there are no female students (out of those surveyed) majoring in natural sciences. On the whole, we found no substantial differences in female students' opinions depending on their year and major of study, which can also be taken into account when compiling training programmes for developing leadership competencies.

The dependency of the will to develop leadership competencies on the "opportunity for development" paradigm showed that among female students who are assured that leadership competencies can be developed, $44.3 \%$ would like to develop "self-awareness of efficacy", $32.9 \%$ of the respondents would like to develop "motivation and persistence", 30.0\$ opted out for "creativity". Among the least sought-after competencies in this group of respondents are "learning through experience" and "taking initiative" $(10.0 \%)$. Female students who answered that developing leadership competencies is to some extent possible, would like to develop such competencies as "financial and economic literacy" - 45.5\%, "motivation and persistence" - $41.6 \%$ and "creativity" $-37.3 \%$. In this group of respondents such competencies as "resource mobilisation" $-7.1 \%$ and "valuing ideas" $-5.9 \%$ - were the least sought-after ones. Female students doubting the possibilities of developing leadership competencies still want to try to develop such competencies as "creativity" - 39.4\%, "working with others" $36.4 \%$ and equally "vision", "mobilizing others" and "financial and economic literacy" $-24.2 \%$. As for the least sought-after competencies, those were "learning through experience" and "valuing ideas" $-9.1 \%$, as well as "looking for opportunities" and "self-awareness of efficacy" $-6.1 \%$. The following result is especially interesting. Female students who answered "No, it is a talent which is either there or not" would still like to try and develop certain leadership competencies, such as "motivation and persistence" - 35.0\%, "working with others" and "vision" $-30 \%$. This group of respondents was least interested in "looking for opportunities" $-10.0 \%$ and "selfawareness of efficacy" $-5.0 \%$. The given results witness that the "nucleus of the competencies" somewhat changes "(im)possibilities of developing leadership competencies" but in this case one can see certain extension of the "nucleus of the competencies" when developing training courses.

\section{Courses and training programs for developing leadership competencies}

A very important aspect in advancing new training programmes and courses is their relevance. When conducting the survey, we tried not only to elicit female students' opinion on the most important leadership competencies and possibilities of their development, but also formedness of the interest to such training programmes and courses (Table 2).

Table 2. Manifestation of the female students' interest in courses and training programmes for developing leadership competencies

\begin{tabular}{|c|c|c|c|c|}
\hline Manifestation of the interest & Frequency & Percent & Valid percent & $\begin{array}{c}\text { Accumulated } \\
\text { percent }\end{array}$ \\
\hline $\begin{array}{c}\text { Very interesting, I will be glad } \\
\text { to take part in them }\end{array}$ & 152 & 40.2 & 40.2 & 40.2 \\
\hline $\begin{array}{c}\text { In theory, they are interesting, } \\
\text { but they are unlikely to come in } \\
\text { handy in practice }\end{array}$ & 77 & 20.4 & 20.4 & 60.6 \\
\hline $\begin{array}{c}\text { I do not know, never came to } \\
\text { think about it }\end{array}$ & 119 & 31.5 & 31.5 & 92.1 \\
\hline Not quite interested & 30 & 7.9 & 7.9 & 100.0 \\
\hline Total & 378 & 100.0 & 100.0 & \\
\hline
\end{tabular}

Most of the female students (40.2\%) are very much interested in such courses and they would be glad to take part in them. $20.4 \%$ of those surveyed indicated that they would be interested in the courses in theory, but they are unlikely to come in handy in practice. $31.5 \%$ respondents do not know or never thought about this question. $7.9 \%$ of those surveyed are not interested in such courses. Therefore, advancing such courses for women could be successful on the market of educational services.

Our $2^{\text {nd }}$ and $4^{\text {th }}$ year students as well as Master programmes students appeared more interested in training programmes. Students of social sciences and humanities and natural sciences displayed more interest in taking courses and training programmes for developing leadership competencies.

One can suppose that students of engineering and technical majors regard leadership from the point of view of marketing innovative engineering solutions, whereas students of social sciences and humanities rather consider leadership to be a managerial activity. However, such a conjecture requires confirmation in further studies. 
We also correlated students' assessment of possibilities of developing leadership competencies and the manifested interest in participation in training programmes and courses for developing these competencies. It appears that female students who are skeptical about the courses would also like to try and develop some leadership qualities.

\section{Personal qualities and competency-based model of a female leader}

After analyzing the results of our survey, we also conducted a group interview during which female students interpreted results of the study. They gave an opinion that the variety of the assessed competencies presented for the analysis was not broad enough. Personal qualities of a female leader were elicited during the interview. Characteristics of a female leader in female students' perception gained attractiveness, for apart from the qualities directly connected with the professional activity students especially underlined the need for such personal qualities as charm, openness and charisma. Apart from that, we singled out personal qualities necessary for successful management activity: ability to handle stress, charm, charisma, energy, motivation, self-criticism, self-discipline, determination, openness, activism and responsibility. Also, female students attempted to create their own model of competencies which would most adequately, in their opinion, represent a female leader.

Substantiating presence of the necessary competencies in a female leader, female students mentioned innovative thinking and profound professional knowledge among most important qualities. Determination and ability to reach new high results also took leading positions among the competencies. In female students' opinions, a female leader should have a defined position, point of view, as well as have competencies of a project manager, such as resource management (including time). For female students it turned out important to not only take responsibilities but also to be able to share these. The ability to form a team and stand unpopular decisions are also, in their opinion, not only components of managerial activity, these competencies are also important for a leader. Respondents also marked out such competencies which, in their opinion, are less intrinsic for male leaders, but which female leaders should possess (which they do): an ability to inspire and persuade others, ability to listen to others, ability to admit one's mistakes.

Thus, a "competency-based portrait" (competency-based model) of a female leader presupposes, in female students' opinions, a deeper interaction with colleagues, built on confidence-building (this is how the ability to listen to others strengthens trust in a leader).

Our survey results also showed that a competency-based model of a female leader is perceived by female students in a somewhat different manned than the competency-based model suggested for analysis, and it includes a considerable number of managerial competencies. Additionally, communicative competencies framework matters a lot, i.e. female leadership is regarded by female students, in terms of interaction with colleagues and employees in the first place, which corresponds with a psychosocial portrait of women's professional activity, in which communications play a crucial role.

\section{Conclusions}

At present, there are quite a few theoretical, philosophical, cultural and practical sociological and psychosocial studies in the research field of leadership gender differences, whereas the phenomenon of female leadership itself is understood quite broadly. Courses and training programmes for developing leadership competencies have been gaining a huge popularity lately, inclusive of university female students wishing to build their future career in professional activity.

A competency-based approach in education presupposes a clear understanding of what leadership competencies (and how) should be formed in students during the period of learning or training. However, a competency-based model of female leadership has not been developed to full extent as of yet. Success of training programmes and courses for developing leadership competencies in females depends in no small part on whether perception of female leadership and nucleus of leadership competencies coincide in coaches and instructors developing courses and female students interested in the courses.

Analysis of our results of an applied sociological study enabled us to draw the following conclusions: First and foremost, courses and training programmes should begin with surveys eliciting female students' perception of leadership itself, significance of female leadership for them, concept of leadership competencies, and priorities in forming separate competencies. Second, curricula of courses and training programmes can be developed for mixed groups of students with different major fields and years of study. Third, courses and training programmes aimed at developing leadership competencies can be designed not only with the purpose of upbringing female leaders, but also with the purpose of personal growth. In this case such educational programmes will attract more female students without orientation on leadership positions in their future professional activity. Fourth, it appears that further research of female students' perception of female leaders' competencies in specified professional spheres of activity is of interest, when a woman can have a role not only of a managerial leader, but also a leader in a narrow sphere of professional activity. 


\section{References}

Adjorlolo FV, Fisher KA, Habbel FI, King KB, Liota JL, Looney MR (2013) Women's Leadership Competencies in Mixed Gender and Single-Gender Environments. Journal of the Indiana University Student Personnel Association, pp. 75-94. https://scholarworks.iu.edu/journals/index.php/jiuspa/article/view/3675 Accessed 2 Sep 2018

Bakster ZhK, Erlikh DB (2017) Zhenskoe liderstvo v landshafte budushhego. In: L.P. Pachikova, F.T. Khamatnurov (eds.) Aktual'nye problemy social'nogo i professional'no-jekonomicheskogo vhozhdenija molodezhi v regional'nuju obshhestvenno-proizvodstvennuju sredu. Materialy Mezhdunarodnoj nauchno-prakticheskoj konferencii 1:51-56.

Bataeva BS (2014) Social'no-psihologicheskie osobennosti zhenshhin-rukovoditelej. In: Jekonomicheskaja psihologija i povedencheskaja jekonomika v uslovijah global'nyh social'nyh i jekonomicheskih izmenenij. Materialy Vserossijskoj nauchnoj konferencii 1:7-10.

Berryman-Fink C, LeMaster BJ, Nelson KA (2003) The Women's Leadership Program: A Case Study. Liberal Education 89(1):59-64.

Brezhneva OA, Tkachenko MA, Bataeva BS (2016) Issledovanija zhenskogo liderstva. In: Sovremennye korporativnye strategii i tehnologii v Rossii. Sbornik nauchnyh statej: V 3 chastjah 1:64-70.

Dolzhenkova AI (2017) Gotovnost' k liderstvu v strukture samosoznanija u zhenshhin-rukovoditelej. In: Vestnik Kaluzhskogo filiala RANHiGS 1:62-68.

Eagly AH, Johannensen-Schmidt MC, van Engen ML (2003) Transformational, Transactional, and Laissez-Faire Leadership Styles. Psychological Bulletin 129(4):569-591. doi: 10.1037/0033-2909.129.4.569

Esser A, Kahrens M, Mouzughi Yu, Eomois E (2018) A female leadership competency framework from the perspective of male leaders. Gender in Management: An International Journal 33(2):138-166. doi: 10.1108/GM06-2017-0077

Finogenova AS (2016) Issledovanie liderstva sredi zhenshhin. Studencheskaja nauka XXI veka 1-1(8):227-229.

Goryunova SV (2014). Fenomen zhenskogo liderstva. In: S.T. Akutina (ed.) Izbrannye voprosy sovremennoj nauki (Moscow: Centr nauchnoj mysli. 2014), pp. 7-37.

Khayrullina AD, Khayrullina YaF (2014) Gendernye osobennosti liderskogo povedenija zhenshhin-rukovoditelej v sovremennom menedzhmente. Jelektronnyj jekonomicheskij vestnik Tatarstana 1: 94-102.

Khwaja T (2017) Finding their Own Voice: Women's Leadership Rhetoric. In: Eddy P., Ward K., Khwaja T. (eds.) Critical Approaches to Women and Gender in Higher Education. Palgrave Macmillan, New York, pp. 41-59. doi: 10.1057/978-1-137-59285-9

Klyukina AA (2016) Zhenskoe liderstvo: sovremennye tendencii. In: Nauka. Universitet. Materialy semnadcatoj mezhdunarodnoj ezhegodnoj nauchno-prakticheskoj konferencii prepodavatelej, studentov i aspirantov 1:93-96.

KPMG (2015) Women's Leadership Study. Moving Women Forward into Leadership Roles. https://home.kpmg.com/content/dam/kpmg/ph/pdf/ThoughtLeadershipPublications/KPMGWomensLeadershipSt udy.pdf. Accessed 14 Aug 2018

Kropachyova AA, Suvorova LS (2016) Transformacija gendernyh stereotipov o zhenskom liderstve. Vestnik Universiteta Rossijskoj akademii obrazovanija 1: 91-95.

Maks ON (2015) Sravnitel'nyj analiz muzhskogo i zhenskogo liderstva: gendernyj aspekt. Ekonomika i upravlenie: problemy, reshenija 2(11): 39-41.

McKinsey \& Company (2008) Women Matter 2. Female Leadership, a Competitive Edge for the Future. https://www.mckinsey.com/ /media/McKinsey/Business\%20Functions/Organization/Our\%20Insights/Women\% 20matter/Women_matter_oct2008_english.ashx. Accessed 4 Sep 2018

Mollaeva EA (2014) Vlijanie vnedrenija idej gendernogo ravenstva sredi molodogo pokolenija na zhenskoe liderstvo. Vektor nauki Tol'jattinskogo gosudarstvennogo universiteta. Serija: Pedagogika, psihologija 1(16):146148 .

Place KR, Vardeman-Winter J (2018) Where are the women? An examination of research on women and leadership in public relations. Public Relations Review 44 (1):165-173. doi: 10.1016/j.pubrev.2017.10.005 
Shetty R (2017) Women Leadership - A Study of Select Women Leaders in the IT Sector in Bangalore city. Dharana - International Journal of Business from M.P. Birla Institute of Management, Bengaluru 11(1):39-52.

Solomon M, Secrest K (2017) Women's Leadership Development Through Networks of Support: An Analysis of the Women's Leadership Circles of Vermont. In: Tirmizi SA, Vogelsang JD (eds.) Leading and Managing in the Social Sector. Management for Professionals. Springer, Cham, pp. 195-218. doi: 10.1007/978-3-319-47045-0_12

Stratan SA (2017) Zhenshhina-rukovoditel'. Zhenskoe liderstvo kak fenomen XXI veka. In: Materialy III Mezhdunarodnoj nauchno-prakticheskoj konferencii, posvjashhennoj 70-letiju kafedry obshhej jekonomicheskoj teorii BashGU: V 3 chastjah 1:52-57.

Volchik V, Klimenko 1, Posukhova O (2018) Socio-economic sustainable development and the precariat: a case study of three Russian cities. Entrepreneurship and Sustainability Issues 6(1):411-428. doi: 10.9770/jesi.2018.6.1(25)

Vyrodova YeE, Demura NA (2016) Znachenie zhenskogo liderstva v sovremennom mire. In: Sodejstvie professional'nomu stanovleniju lichnosti i trudoustrojstvu molodyh specialistov v sovremennyh uslovijah sbornik materialov VIII mezhdunarodnoj nauchno-prakticheskoj konferencii, posvjashhennoj 10-letiju Regional'nogo nauchno-metodicheskogo centra professional'noj adaptacii i trudoustrojstva specialistov: V 2 chastjah 1:128-133.

Yakovlev BP, Okhrimenko IB (2017) Gendernyj podhod: zhenshhiny i liderstvo - problema veka. Obshhestvennye nauki 4-1:293-307.

Yermakova SV (2012) Faktory, vlijajushhie na razvitie zhenskogo liderstva. Aspirant. Prilozhenie k zhurnalu Vestnik Zabajkal'skogo gosudarstvennogo universiteta 2(12):16-20.

Yermakova SV (2013) Teoreticheskie predposylki stanovlenija zhenskogo liderstva. Aspirant. Prilozhenie k zhurnalu Vestnik Zabajkal'skogo gosudarstvennogo universiteta 2(14):68-78 